\title{
CropSyst model for wheat under deficit irrigation using sprinkler and drip irrigation in sandy soil
}

\author{
Tahany NORELDIN ${ }^{1)}$ ABCDEF, Samiha OUDA ${ }^{\text {1) ABCDEF, }}$ \\ Oussama MOUNZER ${ }^{2) \text { ACDEF }}$, Magdi T. ABDELHAMID ${ }^{3)}$ ABCDEF
}

\footnotetext{
1) Water Requirements and Field Irrigation Research Department, Soils, Water and Environment Research Institute, Agricultural Research Center; 9 El-Gamah Street El-Giza, Egypt

2) Irrigation Department, CEBAS-CSIC, Campus Universitario de Espinardo 30100 Espinardo, Apartado 164, Spain

3) Botany Department, National Research Centre, 33 El Behouth Street, Dokki, 12622, Giza, Egypt; e-mail: magdi.abdelhamid@yahoo.com
}

For citation: Noreldin T., Ouda S., Mounzer O., Abdelhamid M.T. 2015. CropSyst model for wheat under deficit irrigation using sprinkler and drip irrigation in sandy soil. Journal of Water and Land Development. No. 26 p. 57-64

\begin{abstract}
CropSyst (Cropping Systems Simulation) is used as an analytic tool for studying irrigation water management to increase wheat productivity. Therefore, two field experiments were conducted to 1) calibrate CropSyst model for wheat grown under sprinkler and drip irrigation systems, 2) to use the simulation results to analyse the relationship between applied irrigation amount and the resulted yield and 3) to simulate the effect of saving irrigation water on wheat yield. Drip irrigation system in three treatments $(100 \%, 75 \%$ and $50 \%$ of crop evapotranspiration $-E T c)$ and under sprinkler irrigation system in five treatments $(100 \%, 80 \%, 60 \%, 40 \%$, and $20 \%$ of ETc) were imposed on these experiments. Results using CropSyst calibration revealed that results of using CropSyst calibration revealed that the model was able to predict wheat grain and biological yield, with high degree of accuracy. Using $100 \%$ ETc under drip system resulted in very low water stress index $(W S I=0.008)$, whereas using $100 \%$ ETc sprinkler system resulted in $W S I=0.1$, which proved that application of $100 \%$ ETc enough to ensure high yield. The rest of deficit irrigation treatments resulted in high yield losses. Simulation of application of $90 \%$ ETc not only reduced yield losses to either irrigation system, but also increased land and water productivity. Thus, it can be recommended to apply irrigation water to wheat equal to $90 \%$ ETc to save on the applied water and increase water productivity.
\end{abstract}

Key words: crop modeling, CropSyst model, deficit irrigation, drip irrigation, sprinkler irrigation, Triticum aestivum, water saving

\section{INTRODUCTION}

Agriculture is central of food security and economic growth in developing countries. However, food production requires substantial amounts of water. $\mathrm{Ag}$ riculture water demand is one of the serious pressures on water sector in Egypt, since $85 \%$ of total available water is consumed in agriculture and coupled with poor irrigation management. Water scarcity is a problem facing Egypt these days. Therefore, irrigation water should be adequately applied to crops to avoid water waste. Hence, the efficiency of water use in agriculture needs to increase in a sustainable manner, i.e. food production (quantitatively and qualitatively) per unit of water used has to be raised [OwEIS, HACHUM 2003].

Another option to increase water productivity is deficit irrigation. Deficit irrigation is an optimizing strategy under which crops are deliberately allowed to sustain some degree of water deficit and yield reduc- 
tion [ENGLiSH et al. 1990]. Application of water to assure less than total water requirements for a crop could increase water productivity and conserve water for irrigating new lands. The adoption of deficit irrigation implies appropriate knowledge of crop water use and responses to water deficits, including the identification of critical crop growth periods and of the economic impacts of yield-reduction strategies [OWEIS, HACHUM 2003]. Although an appreciable step towards more rational use of water was presented, adopting deficit irrigation principles implies the acceptance of a certain level of reduction in yield level [HAMDY et al. 2005]. As long as that certain level of yield reduction is low, there is a large possibility that farmers will adopt it.

Wheat is a very important crop in Egypt, where its production is not enough to meet the demand on it. The crop is more sensitive to the timing of a water deficit period rather than the total reduction of applied irrigation water. Exposing wheat plants to high moisture stress depressed seasonal consumptive use and grain yield [BUKHAT 2005]. During vegetative growth, phyllochron decreases in wheat under water stress [MCMASTER 1997] and leaves become smaller, which could reduce leaf area index [GUPTA et al. 2001] and number of reproductive tillers, in addition to limit their contribution to grain yield [DENCIC et al. 2000]. Furthermore, Wheat is very sensitive to high temperature [SLAFER, SATORRE 2000]. The amount of wheat yield reduction as a result of water stress is affected by the stage of grain development, where early grain development stage is more vulnerable to water stress than latter grain development stage [EL-KHOLY et al. 2005]. Therefore, modeling can assist in determining when to reduce the amount of applied irrigation water to wheat plants and what is the expected yield losses would be.

Crop simulation models are the dynamic simulation of crop growth by numerical integration of constituent processes with the aid of computers [MATTHEWS et al. 2000]. CropSyst (Cropping Systems
Simulation) is a process based simulation model uses dynamic simulation of crop growth to by numerical integration of constituent processes with the aid of computers [STOCKLE et al. 1994; 2003]. The model is characterized by simplifications in describing some processes (e.g. monolayer canopy, constant specific leaf area, absence of daily assimilates partitioning). This makes CropSyst easier to be calibrated and a reduced set of crop parameters is needed. These aspects make CropSyst a useful tool for large-scale simulations and it can be considered a managementoriented model [CONFALONIERI, BECHINI 2004]. In Egypt, the model was validated for wheat grown in sandy soil [IBRAHIM et al. 2012; OUDA et al. 2010]. The model was calibrated for wheat grown in three soil conditions clay, sandy and salt affected soils [OUDA et al. 2013]. The model was applied for wheat grown in salt affected soil [NORELDIN et al. 2013].

Therefore, the objectives of this study were (i) to calibrate CropSyst model for wheat grown under sprinkler and drip irrigation systems; (ii) to use the simulation results to analyze the relationship between applied irrigation amount and the resulted yield; (iii) and to simulate the effect of saving irrigation water on wheat yield.

\section{MATERIALS AND METHODS}

Two field experiments were conducted during the season 2012/2013 at the experimental farm of the National Research Centre, Nubaria region, Egypt, representing the newly reclaimed sandy soils $\left(30^{\circ} 52^{\prime} 00^{\prime \prime} \mathrm{N}\right.$ $\left.31^{\circ} 10^{\prime} 00^{\prime \prime} \mathrm{E}\right)$. The experimental area has an arid climate with cool winters and hot dry summers. Table 1 summarizes the mean climatic data for the experimental site in Nubaria. Some physical and chemical properties of the experimental soil are shown in Table 2 and 3. Irrigation water was obtained from an irrigation channel passing through the experimental area. Some characteristics of the irrigation water used are shown on Table 4. The experimental field was deep

Table 1. Averages weather data on the experimental site in Nubaria in the growing season 2012/2013

\begin{tabular}{|c|c|c|c|c|c|c|c|c|}
\hline \multirow{2}{*}{ Month and year } & \multirow{2}{*}{$\begin{array}{c}\text { Date } \\
\text { from-to }\end{array}$} & \multicolumn{3}{|c|}{ Temperature, ${ }^{\circ} \mathrm{C}$} & \multirow{2}{*}{$\begin{array}{c}\text { Relative humidity } \\
\text { mean, } \%\end{array}$} & \multirow{2}{*}{$\begin{array}{c}\text { Solar radiation } \\
\mathrm{W} \cdot \mathrm{m}^{-2}\end{array}$} & \multirow{2}{*}{$\begin{array}{c}\text { Wind speed } \\
\mathrm{m} \cdot \mathrm{s}^{-1}\end{array}$} & \multirow{2}{*}{$\begin{array}{c}\text { Rainfall } \\
\mathrm{mm}\end{array}$} \\
\hline & & mean & $\max$. & $\min$. & & & & \\
\hline November 2012 & $21-30$ & 17.2 & 22.7 & 11.6 & 59.6 & 141.7 & 7.3 & 0.1 \\
\hline December 2012 & $1-10$ & 17.5 & 23.4 & 11.4 & 32.7 & 142.9 & 2.6 & 0.0 \\
\hline December 2012 & $11-20$ & 15.0 & 19.9 & 9.9 & 33.4 & 143.4 & 13.7 & 0.0 \\
\hline December 2012 & $21-31$ & 14.2 & 19.8 & 8.5 & 44.5 & 144.5 & 1.7 & 0.0 \\
\hline January 2013 & $1-10$ & 12.9 & 17.5 & 8.1 & 72.4 & 160.9 & 2.0 & 0.0 \\
\hline January 2013 & $11-20$ & 11.5 & 16.4 & 6.5 & 72.8 & 158.0 & 2.4 & 0.0 \\
\hline January 2013 & $21-31$ & 13.2 & 17.9 & 8.5 & 74.8 & 145.5 & 2.5 & 0.6 \\
\hline February 2013 & $1-10$ & 13.8 & 15.5 & 12.2 & 74.4 & 170.5 & 1.5 & 1.3 \\
\hline February 2013 & $11-20$ & 12.8 & 16.3 & 9.3 & 75.9 & 175.5 & 2.4 & 0.1 \\
\hline February 2013 & $21-28$ & 14.0 & 19.5 & 8.5 & 77.0 & 203.4 & 4.3 & 0.2 \\
\hline March 2013 & $1-10$ & 14.0 & 19.9 & 8.1 & 79.7 & 227.4 & 4.1 & 0.0 \\
\hline March 2013 & $11-20$ & 15.1 & 20.9 & 9.1 & 65.7 & 252.9 & 4.7 & 0.0 \\
\hline March 2013 & $21-31$ & 16.3 & 22.9 & 9.6 & 73.3 & 295.0 & 7.7 & 0.0 \\
\hline April 2013 & $1-10$ & 21.7 & 30.0 & 13.4 & 61.6 & 315.0 & 3.6 & 0.0 \\
\hline April 2013 & $11-20$ & 19.9 & 27.2 & 12.4 & 57.1 & 300.9 & 3.6 & 0.0 \\
\hline
\end{tabular}

Source: own study. 
Table 2. Chemical analyses of extract of saturated soil at the site of the experiment

\begin{tabular}{|c|c|c|c|c|c|c|c|c|c|c|c|}
\hline \multirow{2}{*}{$\begin{array}{c}\text { Depth } \\
\mathrm{cm}\end{array}$} & \multirow{2}{*}{$\begin{array}{c}\mathrm{pH} \\
1: 2.5 \\
\end{array}$} & \multirow{2}{*}{$\begin{array}{c}E C \\
\mathrm{dS} \cdot \mathrm{m}^{-1} \\
\end{array}$} & \multirow{2}{*}{$\begin{array}{l}S P \\
\% \\
\end{array}$} & \multicolumn{4}{|c|}{ Anions, $\mathrm{meq} \cdot \mathrm{L}^{-1}$} & \multicolumn{4}{|c|}{ Cations, meq $\cdot \mathrm{L}^{-1}$} \\
\hline & & & & $\mathrm{CO}_{3}{ }^{2-}$ & $\mathrm{HCO}_{3}$ & $\mathrm{Cl}^{-}$ & $\mathrm{SO}_{4}{ }^{2-}$ & $\mathrm{Ca}^{2+}$ & $\mathrm{Mg}^{2+}$ & $\mathrm{Na}^{+}$ & $\mathrm{K}^{+}$ \\
\hline $0-20$ & 8.13 & 1.90 & 22.1 & 0.00 & 2.00 & 12.00 & 4.30 & 5.20 & 4.10 & 8.27 & 0.73 \\
\hline $20-40$ & 8.10 & 1.88 & 21.0 & 0.00 & 1.00 & 13.00 & 2.80 & 5.08 & 4.00 & 7.20 & 0.52 \\
\hline $40-60$ & 8.09 & 1.96 & 21.0 & 0.00 & 1.30 & 12.20 & 4.65 & 5.00 & 3.00 & 9.61 & 0.54 \\
\hline
\end{tabular}

Explanations: $E C=$ electrical conductivity, $S P=$ saturation percentage.

Source: own study.

Table 3. Mechanical analyses and the elemental concentration of the soil

\begin{tabular}{|c|c|c|c|c|c|c|c|c|c|c|c|}
\hline \multicolumn{4}{|c|}{ Mechanical analyses of the soil, \% } & \multicolumn{4}{c|}{ Elemental concentration of the soil, $\mathrm{mg}^{\circ} \mathrm{kg}^{-1}$ of soil } \\
\hline coarse sand & fine sand & silt & clay & texture & $\mathrm{N}$ & $\mathrm{P}$ & $\mathrm{K}$ & $\mathrm{Fe}$ & $\mathrm{Zn}$ & $\mathrm{Mn}$ & $\mathrm{Cu}$ \\
\hline 68.9 & 17.4 & 8.4 & 5.3 & sandy & 32.5 & 78.1 & 3.39 & 0.39 & 0.49 & 7.13 & 0.26 \\
\hline
\end{tabular}

Source: own study.

Table 4. Chemical characteristics of irrigation water used

\begin{tabular}{|c|c|c|c|c|c|c|c|c|c|c|}
\hline \multirow{2}{*}{$\begin{array}{c}E C \\
\mathrm{ds} \cdot \mathrm{m}^{-1}\end{array}$} & \multirow{2}{*}{$\mathrm{pH}$} & \multicolumn{4}{|c|}{ Anions, meq $\cdot \mathrm{L}^{-1}$} & \multicolumn{4}{|c|}{ Cations, $\mathrm{meq} \cdot \mathrm{L}^{-1}$} & \multirow{2}{*}{$\mathrm{SAR} \%$} \\
\cline { 3 - 11 } & & $\mathrm{SO}_{4}^{2-}$ & $\mathrm{Cl}^{-}$ & $\mathrm{HCO}_{3}^{-}$ & $\mathrm{CO}_{3}^{2-}$ & $\mathrm{K}^{+}$ & $\mathrm{Na}^{+}$ & $\mathrm{Mg}^{+2}$ & $\mathrm{Ca}^{+2}$ & \\
\hline 0.41 & 7.35 & 1.3 & 2.7 & 0.1 & - & 0.2 & 2.4 & 0.5 & 1.0 & 2.8 \\
\hline
\end{tabular}

Source: own study.

ploughed before planting. First disc harrow, then duck food was used for further preparation of the field for planting. A combined driller that facilitated concurrent application of fertilizer and seeds was used.

In order to achieve the objectives of this study, two irrigation methods were investigated i.e., sprinkler irrigation method (solid-set sprinkler) and drip irrigation (surface drip irrigation). The technical specifications of each irrigation network could be summarized as follows: The solid-set sprinkler irrigation system consisted of the following components: a pump unit (capacity $50 \mathrm{~m}^{3} \cdot \mathrm{h}^{-1}$ ) and control head unit; main, sub-mains and laterals tubes (inside diameters are $150,110,63 \mathrm{~mm}$, respectively; sprinkles line length $18 \mathrm{~m}$, distance between sprinklers $6 \mathrm{~m}$; couplers; sprinkler discharge at operating pressure 3.5 bar is 1.4 $\mathrm{m}^{3} \cdot \mathrm{h}^{-1}$; and other accessories such as valves, bends, plugs and risers. The surface drip irrigation system consisted of the following components: a pump unit (capacity $50 \mathrm{~m}^{3} \cdot \mathrm{h}^{-1}$ ) and control head unit; main, submains and laterals tubes (inside diameters are 150, 110, $63 \mathrm{~mm}$, respectively; manifold lines (inside diameter $2.54 \mathrm{~mm}$ ); lateral lines (inside diameter 16 $\mathrm{mm}$ ); GR drippers (built-in and discharge), lateral lines lengths $15 \mathrm{~m}$; operating pressure 1.5 bar; dripper discharge (4.0 lph); 50 drippers are per each lateral line and the distances between lateral lines is $20 \mathrm{~cm}$; and other accessories such as valves, bends, plugs and risers. The control of pressure and adjusting it by the first valve and pressure gauges at the control head unit, and the time of irrigation by stop watch according to irrigation water requirements, soil and crop type which calculated from specific equations.

The experimental design was complete randomized block with three replicates. Wheat was planted in $2012 / 2013$ under drip irrigation in three treatments $(100 \%, 75 \%$ and $50 \%$ of ETc) and under sprinkler irrigation in five treatments $(100 \%, 80 \%, 60 \%, 40 \%$, and $20 \%$ of crop evapotranspiration; ETC).
A wheat cultivar 'Sakha 93' was planted on 23 November 2012, and harvest was done on 17 April 2013. The driller setting was such that it applied 167 $\mathrm{kg}$ of seed per hectare. All plots received the same amount of fertilizer. The recommended fertilizers were applied as follow: $285 \mathrm{~kg} \mathrm{~N} \cdot \mathrm{ha}^{-1}$ as ammonium nitrate, ten percent applied to the soil before planting and the remainder was six equal doses applied to the soil before each irrigation and until before heading stage, $70 \mathrm{~kg} \mathrm{P}_{2} \mathrm{O}_{5} \cdot \mathrm{ha}^{-1}$ as single superphosphate applied to the soil in two equal doses before planting and at tillering stage, and $115 \mathrm{~kg} \mathrm{~K} \mathrm{~K}_{2} \cdot \mathrm{ha}^{-1}$ as potassium sulphate applied once after 30 days after sowing. All other cultural practices for wheat crop were carried out according to those recommended by the Ministry of Agriculture and Land Reclamation, Egypt.

Leaf area index was measured at three crop growth stages. The dates of these stages were recorded and growing degree days required to the establishment of each growth stage was calculated. Wheat grain and biological yields were measured at harvest and harvest index was calculated. All these measurements needed to calibrate CropSyst model.

For determination of the crop water requirements $C W R$, crop evapotranspiration ETc was calculated under standard conditions as follows:

$$
E T c=E T o \cdot K c
$$

where:

$E T c=$ crop evapotranspiration, $\mathrm{mm} \cdot \mathrm{day}^{-1}$;

$E T o=$ reference crop evapotranspiration, $\mathrm{mm} \cdot \mathrm{day}^{-1}$;

$K c=$ crop coefficient.

The values of $E T C$ and $C W R$ are identical, whereby ETC refers to the amount of water lost through evapotranspiration and $C W R$ refers to the amount of water that is needed to compensate for the loss. ETc calculated from climatic data by directly integrating the effect of crop characteristics into ETo. The Food 
and Agriculture Organization of the United Nations (FAO) Penman-Monteith method is now recommended as the sole standard method for calculating ETo. The Penman-Monteith equation is given by the following equation [ALLEN et al. 1998].

Amount of irrigation water was calculated according to the following equation for the sprinkler irrigation systems:

$$
A W=\frac{E T c}{E a(1-L R)}
$$

where:

$$
\begin{aligned}
A W= & \text { applied irrigation water depth, } \mathrm{mm} \cdot \mathrm{day}^{-1} ; \\
E a= & \text { application efficiency equals } 75 \% \text { for } \\
& \text { sprinkler irrigation system and } 90 \% \text { for } \\
& \text { drip irrigation system; } \\
L R= & \text { leaching requirements equals } 10 \% \text { for } \\
& \text { sprinkler irrigation system and } 90 \% \text { for } \\
& \text { drip irrigation system. }
\end{aligned}
$$

The seasonal irrigation water applied $\left(\mathrm{m}^{3} \cdot \mathrm{ha}^{-1}\right)$ for both sprinkler and drip irrigation systems are shown in Table 5.

Table 5. Amount of irrigation water and number of irrigation applied under sprinkler and drip irrigation systems

\begin{tabular}{|l|c|c|c|}
\hline $\begin{array}{c}\text { Irrigation } \\
\text { system }\end{array}$ & $\begin{array}{c}\text { Treatment } \\
E T c\end{array}$ & $\begin{array}{c}\text { Water amount applied } \\
\mathrm{m}^{3} \cdot \mathrm{ha}^{-1}\end{array}$ & $\begin{array}{c}\text { Irrigation } \\
\text { No. }\end{array}$ \\
\hline \multirow{3}{*}{ Drip } & $100 \%$ & 3709 & 38 \\
\cline { 2 - 4 } & $75 \%$ & 2894 & 38 \\
\cline { 2 - 4 } & $50 \%$ & 2079 & 38 \\
\hline \multirow{4}{*}{ Sprinkler } & $100 \%$ & 4143 & 38 \\
\cline { 2 - 4 } & $80 \%$ & 3405 & 38 \\
\cline { 2 - 4 } & $60 \%$ & 2666 & 38 \\
\cline { 2 - 4 } & $40 \%$ & 1927 & 38 \\
\cline { 2 - 4 } & $20 \%$ & 1189 & 38 \\
\hline
\end{tabular}

Explanations: $E T c=$ crop evapotranspiration. Source: own study.

The CropSyst (Cropping Systems Simulation Model) objective is to serve as an analytical tool to study the effect of cropping systems management on crop productivity and the environment. For this purpose, CropSyst simulates the soil water budget, soilplant nitrogen budget, crop phenology, crop canopy and root growth, biomass production, crop yield, residue production and decomposition, soil erosion by water and pesticide fate. These are affected by weather, soil characteristics, crop characteristics, and cropping system management options including crop rotation, variety selection, irrigation, nitrogen fertilization, pesticide applications, soil and irrigation water salinity, tillage operations, and residue management. The water budget in the model includes rainfall, irrigation, runoff, interception, water infiltration and redistribution in the soil profile, crop transpiration, and evaporation. The nitrogen budget in CropSyst includes nitrogen application, nitrogen transport, nitrogen transformations, ammonium absorption and crop nitrogen uptake. The calculation of daily crop growth, expressed as biomass increase per unit area, is based on a minimum of four limiting factors, namely light, temperature, water, and nitrogen. PALA et al. [1996] suggested that minor adjustments of some of these parameters, accounting to cultivar-specific differences, are desirable whenever suitable experimental information is available. Details on the technical aspects and use of the CropSyst model have been reported elsewhere [STOCKLE et al. 1994; STOCKLE, NELSON 1994].

The model was calibrated using the data obtained from the three experiments. Input files required by CropSyst model for wheat crop were prepared and used to run the model. One management file was prepared represent each irrigation treatment. The date of each phenological stage was used to calculate growing degree days for that stage. Total biomass and grain yield were used for model calibration. The values of the crop input parameters were either taken from the CropSyst manual [STOCKLE, NELSON 1994] or set to the values observed in the experiments. The calibration consisted of slight adjustments of wheat input parameters to reflect reasonable simulations. These adjustments were around values that were either typical for the crop species or known from previous experiences with the model. These parameters were: aboveground biomass-transpiration coefficient $\left(\mathrm{kPa} \cdot \mathrm{kg} \cdot \mathrm{m}^{-3}\right)$ and light to aboveground biomass conversion $\left(\mathrm{g} \cdot \mathrm{MJ}^{-1}\right)$.

The relationship between applied irrigation amount and the resulted wheat yield was analyzed by graphing above ground biomass, as well as water stress index to obtain insights on when water stress occurred.

The effect of saving $10 \%$ of the applied irrigation water on wheat yield was simulated under both irrigation systems. Applied of $10 \%$ of irrigation water in each single irrigation was deducted for each treatment. New irrigations files were developed and used to run CropSyst model.

Land and water productivity were calculated to assess the effect of using deficit irrigation treatments. Land productivity $\left(L P, \mathrm{~kg} \cdot \mathrm{m}^{-2}\right)$ is estimated as the amount of economic yield produced from a unit of land [NYAMAI et al. 2012]. It could be quantified by the following equation:

$$
L P=\text { wheat yield }\left(\mathrm{kg} \cdot \mathrm{ha}^{-1}\right) / 10000
$$

Crop water productivity $W P\left(\mathrm{~kg} \cdot \mathrm{m}^{-3}\right)$ is a quantitative term used to define the relationship between crop produced and the amount of water involved in crop production. It is a useful indicator for quantifying the impact of irrigation scheduling decisions, with regard to water management [FAO 2003].

$W P=$ wheat yield $\left(\mathrm{kg} \cdot \mathrm{ha}^{-1}\right) /$ applied water $\left(\mathrm{m}^{3} \mathrm{ha}^{-1}\right)(4)$

\section{RESULTS AND DISCUSSION}

Application of less than $100 \%$ ETc reduced wheat grain and biological yield with different percentage under both drip and sprinkler systems (Tab. 6). Under 
Table 6. Reduction in wheat grain and biological yield as a result of imposed treatments under drip and sprinkler irrigation systems

\begin{tabular}{|c|c|c|c|c|c|}
\hline \multirow{2}{*}{$\begin{array}{c}\text { Irrigation } \\
\text { system }\end{array}$} & \multirow{2}{*}{$\begin{array}{c}\text { Treatment } \\
E T c\end{array}$} & \multicolumn{2}{|c|}{ Grain yield } & \multicolumn{2}{|c|}{ Biological yield } \\
\hline & & $\begin{array}{c}\text { measured } \\
\mathrm{t} \cdot \mathrm{ha}^{-1}\end{array}$ & $\begin{array}{c}\% \text { of } \\
\text { reduction }\end{array}$ & $\begin{array}{c}\text { measured } \\
\mathrm{t} \cdot \mathrm{ha}^{-1}\end{array}$ & $\begin{array}{l}\quad \% \text { of } \\
\text { reduction }\end{array}$ \\
\hline \multirow{3}{*}{ Drip } & $100 \%$ & 6.78 & - & 21.00 & - \\
\hline & $75 \%$ & 5.40 & 20 & 17.70 & 16 \\
\hline & $50 \%$ & 3.71 & 45 & 14.60 & 30 \\
\hline \multirow{5}{*}{ Sprinkler } & $100 \%$ & 6.20 & - & 19.33 & - \\
\hline & $80 \%$ & 5.10 & 18 & 15.92 & 18 \\
\hline & $60 \%$ & 2.80 & 55 & 12.25 & 37 \\
\hline & $40 \%$ & 1.85 & 70 & 9.13 & 53 \\
\hline & $20 \%$ & 1.09 & 82 & 6.10 & 68 \\
\hline
\end{tabular}

Explanations: $E T c=$ crop evapotranspiration.

Source: own study.

drip irrigation wheat grain yield was reduced by 20 and $45 \%$ under application of 75 and $50 \%$ ETc. However, the losses in biological yield was lower, i.e. 16 and $30 \%$. Similar trend was observed under sprinkler irrigation, where reduction in biological yield was higher than reduction in grain yield, except for application of $80 \%$ ETc, where reduction in both grain and biological yield was similar, i.e. 18\%. This result implied that $20 \%$ reduction in the applied irrigation water, the reduction in both grain and biological yield could be similar (Tab. 6). These results suggested that high wheat yield losses could occurred in sandy soil under sprinkler irrigation if $20 \%$ or more of the applied irrigation water was deducted.

There were good agreements between measured and predicted grain and biological wheat yield (Tab. 7). Percentage of difference between measured and predicted yield was low. RMSE values was 0.03 and 0.14 $\mathrm{t} \cdot \mathrm{ha}^{-1}$ for grain and biological yield, respectively. The value of $d$ was 0.97 in both growing seasons. Similar results were obtained by OUDA et al. [2010], IBRAHIM et al. [2012] and OUDA et al. [2013] where the value of RMSE was low and the value of $d$ was high.

Table 7. Measured versus predicted wheat grain and biological yield grown under drip and sprinkler irrigation systems

\begin{tabular}{|c|c|c|c|c|c|c|c|}
\hline \multirow{2}{*}{ Irrigation system } & \multirow{2}{*}{$\begin{array}{c}\text { Treatment } \\
E T c\end{array}$} & \multicolumn{3}{|c|}{ Grain yield, $\mathrm{t} \cdot \mathrm{ha}^{-1}$} & \multicolumn{3}{|c|}{ Biological yield, $\mathrm{t} \cdot \mathrm{ha}^{-1}$} \\
\hline & & measured & predicted & $P D \%$ & measured & predicted & $P D \%$ \\
\hline \multirow{3}{*}{ Drip } & $100 \%$ & 6.78 & 6.71 & 1.00 & 21.0 & 20.97 & 0.24 \\
\hline & $75 \%$ & 5.40 & 5.39 & 0.20 & 17.7 & 17.39 & 1.64 \\
\hline & $50 \%$ & 3.71 & 3.69 & 0.52 & 14.6 & 14.77 & 1.35 \\
\hline \multirow{5}{*}{ Sprinkler } & $100 \%$ & 6.20 & 6.15 & 0.40 & 19.33 & 19.21 & 0.57 \\
\hline & $80 \%$ & 5.10 & 5.08 & 0.37 & 15.92 & 15.88 & 0.23 \\
\hline & $60 \%$ & 2.80 & 2.83 & 0.44 & 12.25 & 12.28 & 0.27 \\
\hline & $40 \%$ & 1.85 & 1.83 & 1.08 & 9.13 & 9.15 & 0.25 \\
\hline & $20 \%$ & 1.09 & 1.09 & 0.14 & 6.10 & 6.03 & 1.10 \\
\hline$R M S E$ & & 0.03 & & & 0.14 & & \\
\hline$d$ & & 0.97 & & & 0.97 & & \\
\hline
\end{tabular}

Explanations: $E T c=$ crop evapotranspiration

Source: own study.

The accumulation of above ground biomass under drip irrigation was higher, compared with it under sprinkler irrigation (Fig. 1). Results in Fig. 2 indicated that low water stress prevailed under sprinkler irrigation in the beginning of vegetative growth. The highest water stress index WSI value was 0.1. However, under drip irrigation, WSI was very low, i.e. 0.008, which implied that the applied irrigation amounts was enough to ensure highest yield.

The rate of above ground biomass accumulation was the highest under application of $100 \%$ ETc while the lowest under application of 50\% ETc (Fig. 3). Water stress existed during flowering stage under application of $75 \%$ ETC as a result wheat yield was reduced by $45 \%$ (Tab. 4). The value of WSI was the highest under the application of 50\% ETc, where water stress prevailed during flowering stage and most grain filling stage (Fig. 4). Water stress prevailed during vegetative growth caused reduction in phyllochron decreases in wheat under water stress [MCMASTER 1997] and leaves become smaller, which could reduce leaf area index [GUPTA et al. 2001]. Thus, assimilates can be reduced and its partitioning to plant parts also reduced and that negatively affected the final yield. Furthermore, water stress prevailed in reproductive stage under application of $50 \%$ ETC doubled damage as a result low productive tillers and cause negative effect of water stress on grain development [EL-KHOLY et al. 2005].

Under sprinkler irrigation, above ground biomass were obviously reduced as a result of reducing applied water to 80 and $60 \%$ ETC during vegetative and reproductive growth (Fig. 5). Furthermore, similar reduction in accumulated above ground biomass was noticed under application of 40 and $20 \%$, although reduction of in the accumulated above ground biomass was observed in reproductive growth when $40 \%$ ETc was applied. Furthermore, the reduction in the accumulated above ground biomass during vegetative growth under 60, 40 and $20 \%$ ETc were close to each other, which implies that the water stress in the vegetative growth under these three treatments was maximum. However, differences in the accumulated above ground biomass during reproductive growth were highly shown, where application of $20 \%$ ETc greatly reduced reproductive growth (Fig. 5), as a result of high water stress existed this phase, i.e. WSI was 0.8 (Fig. 6). 


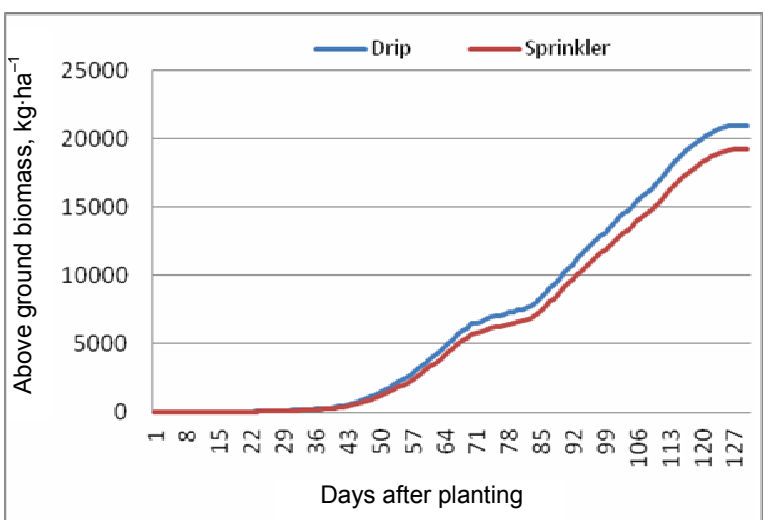

Fig. 1. Comparison between wheat above ground biomass under drip and sprinkler irrigation; source: own study

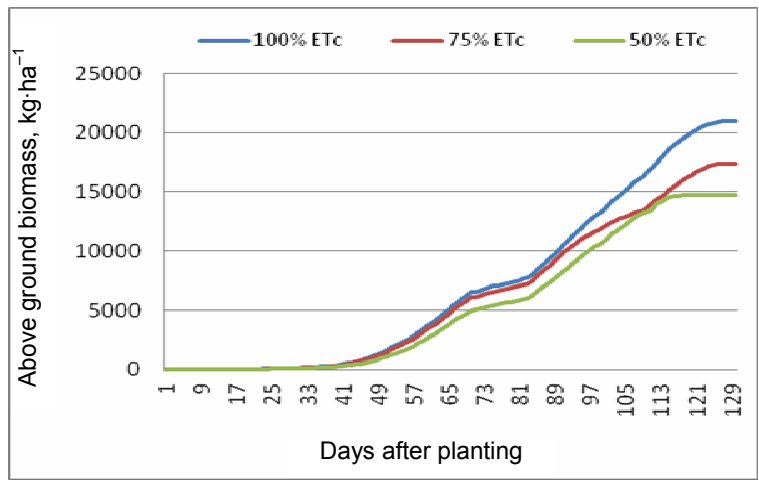

Fig. 3. Comparison between wheat above ground biomass under three drip irrigation treatments;

$E T c=$ crop evapotranspiration; source: own study

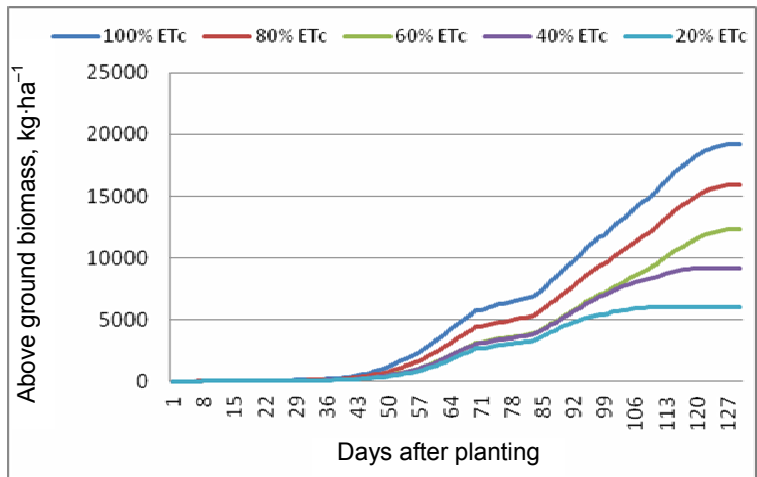

Fig. 5. Comparison between wheat above ground biomass under five sprinkler irrigation treatments;

$E T c=$ crop evapotranspiration; source: own study

As a result of high yield losses under deficit irrigation, the effect of application of $90 \%$ of full irrigation on wheat grain yield was tested. Results in Table 8 indicated that wheat grain yield could be reduced by 3 and $4 \%$ under drip and sprinkler irrigation, respectively. These low percentages of yield losses can be tolerated by farmers and easy to adopt to save irrigation water. These saved amounts can be used to irrigate more land to produce wheat and compensate for these low losses. Figure 7 indicated that accumulated above ground biomass were lower under sprinkler

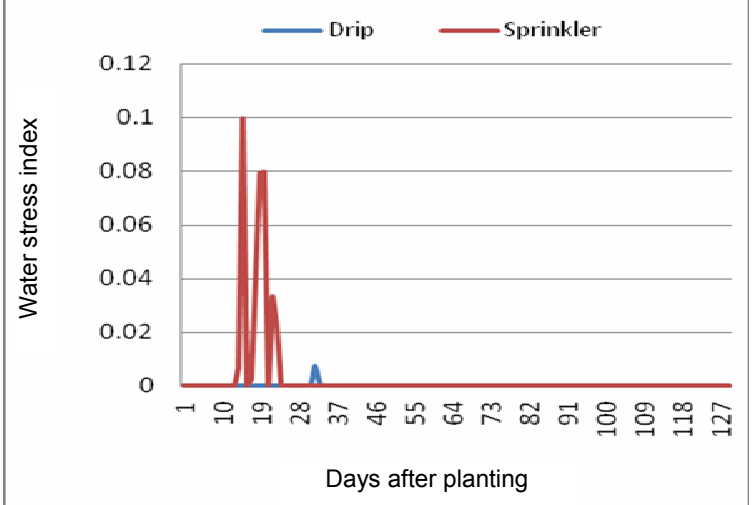

Fig. 2. Comparison between water stress index for wheat under drip and sprinkler irrigation; source: own study

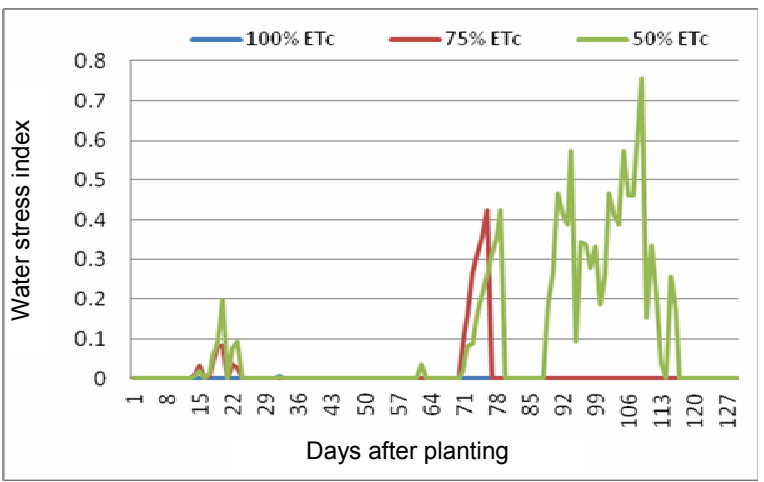

Fig. 4. Comparison between water stress index for wheat under three drip irrigation treatments;

$E T c=$ crop evapotranspiration; source: own study

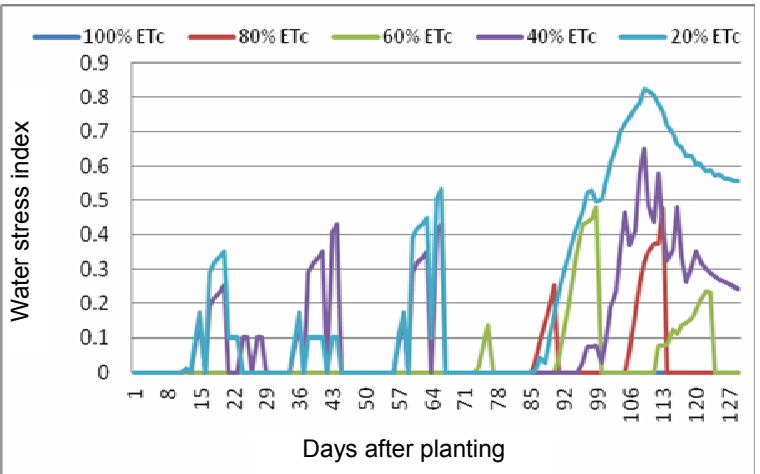

Fig. 6. Comparison between water stress index for wheat under five sprinkler irrigation treatments;

$E T c=$ crop evapotranspiration; source: own study

system using $90 \%$ of full irrigation. These applied amounts caused low water stress during vegetative growth (Fig. 8) and no water stress during grain filling period under both irrigation systems.

Regarding to land productivity $L P$, it was reduced as the amount of applied water was reduced. Furthermore, $L P$ was higher under drip irrigation, compared to sprinkler irrigation (Tab. 9). This can be attributed to higher yield was produced under drip system, compared to sprinkler system. However, $10 \%$ saving in the applied water under either drip or sprinkler system 
Table 8. Measured versus predicted wheat grain yield under $10 \%$ saving in irrigation water

\begin{tabular}{|l|c|c|c|}
\hline \multirow{2}{*}{ Irrigation system } & \multicolumn{3}{|c|}{${\text { Grain yield, } \mathrm{t} \cdot \mathrm{ha}^{-1}}^{-1}$} \\
\cline { 2 - 4 } & measured & predicted & $P R \%$ \\
\hline Drip & 6.78 & 6.58 & 3 \\
\hline Sprinkler & 6.15 & 5.89 & 4 \\
\hline
\end{tabular}

Explanations: $P R \%=$ percentage of reduction between measured and predicted values.

Source: own study.

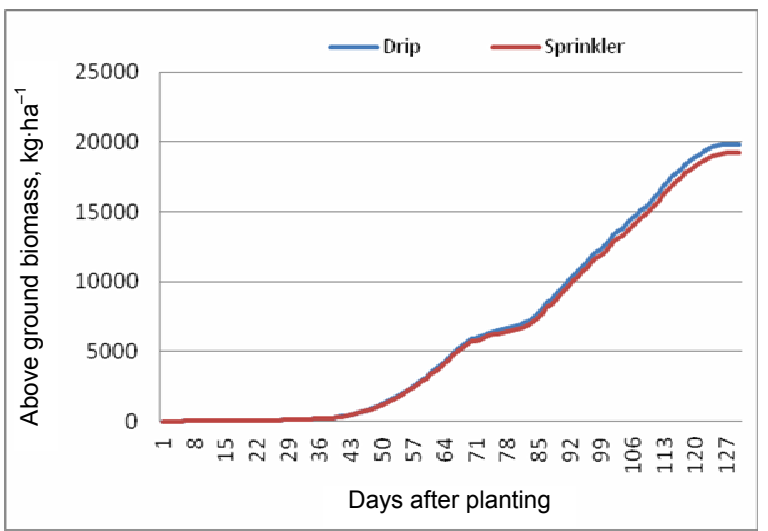

Fig. 7. Simulated above ground biomass for wheat grown under drip and sprinkler system with $90 \%$ of full irrigation under both irrigation systems; source: own study

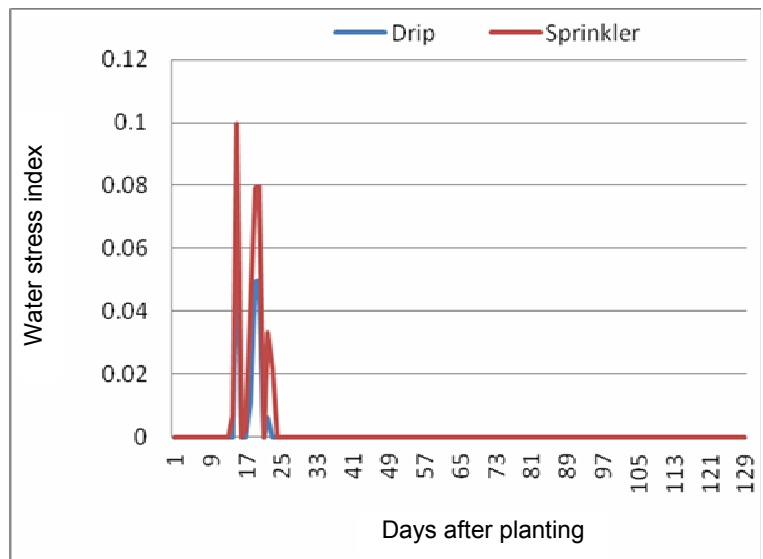

Fig. 8. Simulated water stress index for wheat grown under drip and sprinkler system with $90 \%$ full irrigation under both irrigation systems; source: own study

Table 9. Land and water productivity for wheat grown under drip and sprinkler irrigation systems

\begin{tabular}{|c|c|c|c|}
\hline $\begin{array}{c}\text { Irrigation } \\
\text { system }\end{array}$ & $\begin{array}{c}\text { Treatment } \\
E T c\end{array}$ & $\begin{array}{c}\text { Land productivity } \\
\mathrm{kg} \cdot \mathrm{m}^{-2}\end{array}$ & $\begin{array}{c}\text { Water productivity } \\
\mathrm{kg} \cdot \mathrm{m}^{-3}\end{array}$ \\
\hline \multirow{4}{*}{ Drip } & $100 \%$ & 0.68 & 1.83 \\
\cline { 2 - 4 } & $90 \%$ & 0.66 & 1.97 \\
\cline { 2 - 4 } & $75 \%$ & 0.54 & 1.87 \\
\cline { 2 - 4 } & $50 \%$ & 0.37 & 1.79 \\
\hline \multirow{4}{*}{ Sprinkler } & $100 \%$ & 0.62 & 1.49 \\
\cline { 2 - 4 } & $90 \%$ & 0.59 & 1.58 \\
\cline { 2 - 4 } & $80 \%$ & 0.51 & 1.50 \\
\cline { 2 - 4 } & $60 \%$ & 0.28 & 1.06 \\
\cline { 2 - 4 } & $40 \%$ & 0.19 & 0.96 \\
\cline { 2 - 4 } & $20 \%$ & 0.11 & 0.91 \\
\hline
\end{tabular}

Source: own study. reduce $L P$ by low values, compared to the other deficit treatments.

With respect to water productivity $W P$, reduction in the applied water increased it until 25 and $20 \%$ of the applied water to drip and sprinkler systems, respectively was deducted. If more water was deducted under either system, $W P$ was reduced. Moreover, the highest $W P$ was obtained when $90 \%$ ETc was applied under either system (Tab. 9). OUDA et al. [2010] obtained similar value for $W P$ to what was obtained in Table 9 equal to $1.35 \mathrm{~kg} \cdot \mathrm{m}^{-3}$. Furthermore, IBRAHIM et al. [2012] obtained $W P$ value equal to $1.37 \mathrm{~kg} \cdot \mathrm{m}^{-3}$.

\section{CONCLUSIONS}

CropSyst (Croping Systems Simulation) model predictions of wheat grain and biological yield were close to the measured values. The model was able to simulate daily water stress throughout growing season. Application of $90 \%$ ETC not only reduced yield losses to either irrigation system, but also increased water productivity. Land productivity was reduced under all deficit irrigation treatments, but with low value. It could be recommended to apply irrigation water to wheat equal to $90 \% E T c$ to save on the applied water and increase water productivity.

\section{Acknowledgements}

This work was part of collaborative project number: 245159, titled: SIRRIMED-Sustainable use of irrigation water in the Mediterranean region, supported by The EUFP7-KBBE-2009-3.

\section{REFERENCES}

Allen R.G., Pereira L.S., Raes D., Smith M. 1998. Crop evapotranspiration. Guidelines for computing crop water requirements. FAO Irrigation and Drainage Paper. No. 56. Rome. FAO pp. 300.

BuKHAT N.M. 2005. Studies in yield and yield associated traits of wheat (Triticum aestivum L.) genotypes under drought conditions. MSc Thesis. Department of Agronomy. Sindh Agriculture University, Tandojam, Pakistan.

CONFAlONIERI R., BECHINI L. 2004. A preliminary evaluation of the simulation model CropSyst for Alfalfa. European Journal of Agronomy. No. 21. Iss. 2 p. 223-237.

Dencic S., Kastori R., Kobiljski B., Duggan B. 2000. Evaporation of' grain yield and its components in wheat cultivars and land races under near optimal and drought conditions. Euphytica. No. 1 p. 43-52.

El-Kholy M.A., Ouda S.A., Gaballah M.S., Hozayn M. 2005. Predicting the interaction between the effect of anti-transpirant and weather on productivity of wheat plant grown under water stress. Journal of Agronomy. No. 4 p. $75-82$.

English M., Musick J.T., Murty V.V.N. 1990. Deficit irrigation. In: Management of farm irrigation systems. Ed. G.J. Hoffman, T.A. Howell, K.H. Solomon. St Joseph, Michigan. ASAE p. 631-663.

FAO 2003. Unlocking the water potential of agriculture: FAO Corporate Document Repository. Rome pp. 62.

GuPTA N. K., GuPTA S., Kumar A. 2001. Effect of water stress on physiological attributes and their relationship with growth and yield in wheat cultivars at different 
growth stages. Journal of Agronomy. No. 86 p. $1437-$ 1439

Hamdy A., SARdo V., Ghanem K.A.F. 2005. Saline water in supplemental irrigation of wheat and barley under rain fed agriculture. Agricultural Water Management. No. 78 p. 122-127.

IBRAhim M.M., OUdA S.A., TAHA A., El AfANDI G., EID S.M. 2012. Water management for wheat grown in sandy soil under climate change conditions. Journal of Soil Science and Plant Nutrition. No. 12 p. 195-210.

Matthews R., Stephens W., Hess T., Mason T., Graves A. 2000. Applications of soil/crop simulation models in developing countries. DFID NRSP Programme Development Report PD082. Silsoe, UK. Institute of Water and Environment, Cranfield University pp. 175.

MCMaster G.S. 1997. Phonology, development, and growth of wheat Triticum aestivum L. shoot apex: A review. Advances in Agronomy. No. 59 p. 63-118.

Noreldin T., Ouda S., Abouelenein R. 2013. Development of management practices to address wheat vulnerably to climate change in North Delta. Proceeding of the 11th International Conference on Development of Dry Lands. Beijing. March 18-21, 2013 p. 982-995.

Nyamai M., Mati B.M., Home P.G., Odongo B., Wanjogu R., ANDTHURANIRA E.G. 2012. Improving land and water productivity in basin rice cultivation in Kenya through System of Rice Intensification (SRI). Agricultural Engineering International: CIGR Journal. No. 14 (2) p. 1-9.

Ouda S., El-Afandi G., Noreldin T. 2013. Modeling climate change impacts and adaptation strategies for crop production in Egypt: an overview. In: Climate change and water resources. Eds. T. Younos, C.A. Grady. Berlin-Heidelberg. Springer p. 99-120.
Ouda S.A., Sayed M., El Afandi G., Khalil F.A. 2010. Developing an adaptation strategy to reduce climate change risks on wheat grown in sandy soil in Egypt. In: Tenth International Conference on Development of Drylands. Meeting the Challenge of Sustainable Development in Drylands under Changing Climate - Moving from Global to Local. International Dryland Development Commission, 12-15 December 2010, Cairo, Egypt p. 34-35.

OWEIS T.Y., HACHUM A.Y. 2003. Improving water productivity in the dry areas of west Asia and north Africa. In: Water productivity in agriculture: limits and opportunities for improvement. Eds. J.W. Kijne, R. Barker, D. Molden. CAB International p. 179-198.

Pala M., Stockle C.S., Harris H.C. 1996. Simulation of durum wheatTriticum turgidum ssp Durum growth under different water and nitrogen regimes in a Mediterranean environment using CropSyst. Agricultural Systems. No. 512 p. $147-163$.

Slafer G.A., SATORRE E.H. 2000. Wheat: ecology and physiology of yield determination. CRC Press. ISBN 9781560228752 pp. 503.

Stockle C.O., Donatelli M., Nelson R. 2003. CropSyst, a cropping systems simulation model. European Journal of Agronomy. No. 18 p. 289-307.

Stockle C.O., Martin S., CAmpBell G.S. 1994. CropSyst, a cropping systems model: water/nitrogen budgets and crop yield. Agricultural Systems. No. 46 p. 335-359.

Stockle C.O., Nelson R. 1994. Cropping Systems Simulation: Model Users Manual (Version 1.02. 00). Biological Systems Engineering Department, Washington State University pp. 167.

\section{Tahany NORELDIN, Samiha OUDA, Oussama MOUNZER, Magdi T. ABDELHAMID}

\section{Model CropSyst do nawodnień pszenicy metodą deszczowania i metodą kroplową na glebach piaszczystych}

\section{STRESZCZENIE}

Slowa kluczowe: model CropSyst, modelowanie plonów, nawodnienia deszczowniane, nawodnienia kroplowe, oszczędność wody, potrzeby nawodnień, Triticum aestivum

CrosSyst (ang. Cropping Systems Simulation) wykorzystano jako narzędzie analityczne do zarządzania wodą do nawodnień w celu zwiększenia produktywności pszenicy. Przeprowadzono dwa eksperymenty terenowe w celu: 1) kalibracji modelu CropSyst w odniesieniu do pszenicy uprawianej w warunkach nawodnień deszczownianych i kroplowych, 2) zastosowania wyników symulacji do analizy zależności między wielkością nawodnień a plonem i 3) symulacji wpływu oszczędności wody użytej do nawodnień na plon pszenicy. W eksperymentach zastosowano trzy warianty nawodnień kroplowych $(100 \%, 75 \%$ i $50 \%$ ewapotranspiracji $-E T c)$ i pięć wariantów nawadniania deszczownianego $(100 \%, 80 \%, 60 \%, 40 \%$ i $20 \%$ ETc). Wyniki kalibracji wykazały, że wartość $R M S E$ wynosiła 0,03 i 0,14 th ha ${ }^{-1}$ odpowiednio dla ziarna i biomasy. Model umożliwiał symulację dobowego stresu wodnego w ciagu całego sezonu wegetacyjnego. W wariancie $90 \%$ ETc nie tylko stwierdzono zmniejszenie strat plonu w każdym z systemów nawodnień, ale także zwiększenie produktywności wody. Dlatego można zalecić stosowanie dawki 90\% ETc w celu oszczędności wody i zwiększenia jej produktywności. 